\title{
Exploring School Preparedness to Develop Safe School in Disaster-prone Areas
}

\author{
Siti Hadiyati Nur Hafida ${ }^{1}$, Sutama ${ }^{2}$, Ayu Fatonah ${ }^{3}$ \\ \{shnh421@ums.ac.id¹, sut197@ums.ac.id², ayufatonah06@gmail.com³ $\}$
}

\begin{abstract}
Geography Education Department, Universitas Muhammadiyah Surakarta ${ }^{1}$, Mathematic Education Department, Universitas Muhammadiyah Surakarta ${ }^{2}$, Geography Education Department, Universitas Muhammadiyah Surakarta ${ }^{3}$
\end{abstract}

\begin{abstract}
Schools become one of the public facilities that are vulnerable to disasters. Damage school facilities can cause the future of the young generation to be threatened. Schools in disaster-prone areas must have preparedness in coping disasters so children will safe and comfortable while in school. This research is a mixed research, with principals and teacher as respondents. Data collection techniques using questionnaires, interviews, and documentation. The variables used to measure school preparedness are policies, emergency response plans, disaster warnings, and resource mobilization. The results of the study indicate that the preparedness of schools to realize safe schools has an unprepared index, with a value of 50.8. Aspects that need to be improved to develop safe schools include the presence of emergency response plans, disaster warnings, and resource mobilization. Schools still very limited in providing disaster warning systems and disaster training, so they must prepare policies, infrastructure, and suprastructure of disasters.
\end{abstract}

Keywords: Safe school, preparedness, disaster area

\section{Introduction}

Indonesia is a "market" of disasters; numerous types of disaster befall Indonesia. Based on the data from BNPB (The National Disaster Management Agency) in 2016, the disasters doubly increased, compared to those in 2007; there were 816 disasters in 2007, while in 2016 it increased to 1985. Indonesian Disaster Information Data (DIBI) in 2019 states that the occurrence of disasters in the period of 2018 - 2019 is 5221. The number of those disasters cannot be avoided by the Indonesian people considering the types of disaster are mostly geological disasters, namely earthquakes, landslides and volcanic eruptions. These types of disaster cannot be stopped by humans; humans can only minimize the impacts of those geological disasters.

Disasters are incidents that cause victims, both casualties and property. In the period of 2018 - 2019, there are around 5086 Indonesians became the victims of disasters (DIBI, 2019). 
The large number of victims of the disasters is due to the low level of disaster preparedness that is owned by Indonesians. Community groups that have a high level of vulnerability to disasters are children and women [7]. The cause to this is that children have less access to disaster preparedness, mitigation and rehabilitation [1]. Children's access is very limited; they are not able to independently access disaster information and are very dependent on adults around them. Moreover, children's vulnerability to disasters is because of their limited understanding of the risks around them, which results in the absence of preparedness in facing disasters [9]. This increases the disaster vulnerability of children.

Children spend most of their time in school, however, as many as 250000 schools or $75 \%$ of total schools in Indonesia are in disaster-prone areas (BNPB, 2019). It made school building become one of the buildings that are subjects to disasters. Of all available public facilities, children who are in school during a disaster are the most vulnerable group [11, 15]. In 2015, there were around 26856 school units that have minor to serious damage due to the disaster. The damage to those schools can threaten millions of future generations [5]. When school buildings are damaged, children and young people cannot continue their education. Disaster risk reduction in schools becomes very important given the condition of Indonesia which is subject to disasters [13].

Based on the data, there are still many schools that are not safe for children. A learning environment that has a positive and safe impact is very necessary for students to learn [17], especially in disaster-prone areas. The ultimate goal in education is to prosper and delight students, therefore, the school does not only function as a place to carry out the learning process; it must be able to pay attention to the security and to teach social behavior. Safe schools must be able to balance the physical and psychological security so that a positive learning environment is realized [17].

Safety as a behavior to protect children from risk. Children's safety becomes a special concern because children do not have fear and do not know the consequences of their actions. Elementary school students are students who are in the middle childhood period [6]. Middle childhood period shows that elementary school students have conditions that are psychologically vulnerable, therefore, students will easily experience stress during a disaster. The school environment has a direct impact on student's welfare. Schools play an important role in disaster management, this is because schools are a source of knowledge and able to improve the students' knowledge and skills in facing the disasters. The teacher is able to encourage the students to develop their psychological responses in disaster perception situations.

Schools can be utilized in disaster risk reduction efforts. Through education, everyone's attitudes and behavior may change. Students who have gained the understanding of disasters will have more knowledge, decreased levels of anxiousness related to hazards and more accurate perceptions of disaster risk $[19,20]$. Safe schools must ensure that the learning process goes well, teachers are able to teach and students can learn in a safe environment, so that the students fear can be reduced. Safe schools are the optimal foundation in social, emotional and academic learning. It is because the school's climate is safe, participatory, and 
responsive to each student's activity [21]. Feeling safe at school can enhance classroom engagement, academic success, and overall student well-being [3, 18, 23].

The learning process cannot be carried out in an unsafe environment. To create a safe school environment, especially in disaster-prone areas is a big challenge for schools. Everyone in the school environment must be able to encourage the realization of a safe school, so students will feel more comfortable in school. The teacher is the one among others who is at the forefront of student's safety issues. The teacher is a person who is very close to the students and able to interact every day with them. However, the teacher often does not know how to help the students in disaster situations. The preparedness of the school in improving the ability to deal with disasters is indispensable for schools in disaster-prone areas, so the students can safely and comfortably learn. The preparedness of schools to realize the safe schools is very important considering 66 million children worldwide are affected by the disaster [8]. Schools have an important role in promoting student's safety in risk reduction strategies because schools can be easily reached by students to gain knowledge about disaster risk, causes and safety procedures [4]. Therefore, there is a needed for school preparedness in coping disasters, especially for areas that are in disaster prone areas.

\section{Research Method}

This research was a mixed research, aimed at obtaining a systematic picture of the preparedness of schools in creating safe schools in disaster-prone areas. This research was conducted in Karanganyar Regency, with two schools as the research locations: Muhammadiyah Elementary School Jatiyoso and Muhammadiyah Islamic Elementary School Munggur. Both schools have the higher risk of disaster than the other elementary schools in the area. Muhammadiyah Elementary School Jatiyoso has a risk of landslides, while Muhammadiyah Islamic Elementary School Munggur has a risk of tornadoes. The total respondents in this study were 18 teachers and 2 school principals. The sample used is a saturated sample, so that all teachers and principals of the two schools participated in this study. The data collection techniques used were using questionnaires and doing observations.

The data analysis techniques used was descriptive statistical technique. It was started by measuring the level of disaster preparedness of the teachers and principals. The variables in measuring the level of disaster preparedness for principals include: disaster preparedness policies, emergency response plans, disaster warnings, and resource mobilization; while variables for teachers include: knowledge of disasters, activity plans of disasters, and disaster warnings [10]. The level of disaster preparedness was categorized into 5, namely very ready, ready, almost ready, less ready and not ready (Table 1). From the results of the statistical analysis, the school's preparedness in creating the safe schools in disaster-prone areas was then analyzed. 
Table 1. Level of Disaster Preparedness by LIPI

\begin{tabular}{lll}
\hline No & Category & Value \\
\hline 1 & Very ready & $80-100$ \\
2 & Ready & $65-79$ \\
3 & Almost ready & $55-64$ \\
4 & Less ready & $40-54$ \\
5 & Not ready & $<40$ \\
\hline
\end{tabular}

\section{Result and Discussion}

\subsection{The Level of the Teachers Preparedness}

Teachers are often regarded as people who must be modeled on this matter, therefore the preparedness of teachers in facing disasters greatly influences students' preparedness in facing disasters. If the teacher's preparedness in facing the disasters is good, the preparedness of the students will be also good, and the vice versa. Furthermore, the teacher has a great responsibility in guiding the students at school. The guidance is not only related to the learning skills but also the social skills. One of the guidances can be in the form of providing knowledge and actions taken during a disaster. Based on Fig. 1, there is an index of 65.33 which indicates that the teacher's knowledge related to disasters were in the ready category. The huge number of victims during the disasters was caused by the lack of knowledge about disasters and the lack of preparedness in facing the disasters [14].

The high index of disaster knowledge possessed by teachers is influenced by their experience of facing disasters. Experience, knowledge, and preparedness are inseparable things; they will always relate to each other. Teachers who are in disaster-prone areas definitely know the condition of the areas, even most teachers have been victims of disasters. The experience in facing the disasters is ultimately utilized by teachers to provide knowledge to the students so that the number of the disaster victims can be minimized. Experience will encourage the realization of adaptation in facing the next disasters [12]. By having a disaster experience, a teacher is able to improve his perception regarding disaster risk and is able to strengthen the motivation in disaster preparedness behavior [22].

Knowledge about disasters can improve teacher's understanding regarding disasters. Understanding is different from knowledge. Understanding shows that every teacher knows the precautionary actions and the impacts of each action so that the teacher is able to provide good examples to students. The deep understanding of disaster encourages teachers in disaster-prone areas to be able to integrate all the knowledge they have in developing disaster preparedness plans. The teacher's perception of the disaster preparedness plan has an index of 
87.74 , and is categorized as very ready. The disaster preparedness plans cannot be realized without knowledge and understanding related to disaster. With a good understanding of disaster, the teacher is able to develop a disaster preparedness plan. Disaster preparedness plans will help teachers and the community to always prepare themselves in disaster emergency situations so that the number off the disaster victims can be minimized.

Experience in facing disasters encourages teachers to be more sensitive to early warning systems and makes them more enthusiastic about collaborating in disaster management [2]. In this research, the teacher's perception of disaster warning has an almost ready category, with an index value of 60.3. The low level of teacher's perceptions on disaster warnings indicates that there was only a limited number of the availability of disaster warning devices in the school. Moreover, it also implies that the devices were rarely available in the schools. Karanganyar Regency is a district that is prone to landslides and tornadoes, however, the availability of the disaster early detection devices is still very limited. The teachers had good knowledge and understanding of disasters, therefore the teachers know the indication of landslides and tornadoes. The disaster warning device that teachers knew and often used when disaster occurred was kentongan. By using kentongan, the teacher were able to provide the information regarding the disaster to the community, especially to the elementary school students. During the learning process, the teacher always gave the students an understanding of the condition of the area and the use of kentongan. To minimize the number of the disaster victims, the elementary school students must know the meaning of each knock of kentongan.

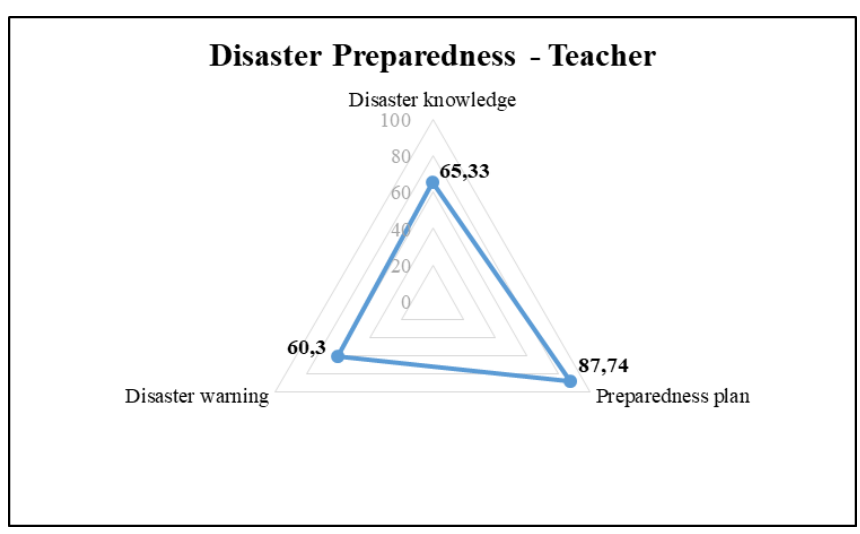

Fig. 1. Perception of Teachers Preparedness

\subsection{The Level of the Principal's Preparedness}

The principal is a leader in an educational institution. The school principal who is responsive to disaster problems can encourage the realization of disaster-safe schools, because the principal is a person who is able to formulate the policies in a school. All policies prepared by the school will require the approval from the principal. The principal's preparedness in facing disasters can be measured through the preparedness policies, disaster warnings and emergency response plans. 
In realizing disaster-safe schools, school principals must be able to prepare disaster preparedness policies. The policy will be related to disaster-related regulations in a school. The disaster preparedness policy has an index of 45.83, with the less ready category. This was indicated by the lack of efforts to increase the teacher's knowledge and skills regarding disaster preparedness and budget allocation for school preparedness. Disasters are often considered as "God's act", therefore the school does not have any preparedness in facing disasters. Well-studied emergency practices tend to increase the possibility that staff and students will respond in an informed and predictable manner when they are in real emergency situations at schools. Students will find it easier to know disaster information if it is supported by the disaster policies in school. As students have very limited access to information from outside the school, the disaster policy in their school will greatly encourage their preparedness in facing disasters.

The low index of disaster policy ultimately led to the low index of emergency response plan. The emergency response plan only has an index of 37.50. The proof to this was the absence of maps of landslide and tornadoes evacuation routes and temporary evacuation sites, and there were only evacuation marks. According to Reference 15, students need evacuation routes and temporary evacuation sites so that if disasters occur, people can go to temporary evacuation sites quickly through the right route to reduce the victims' risks. Not only did the schools fail to provide a route and temporary evacuation site, they also rarely conducted disaster training for teachers and students. The absence of disaster training resulted in the lack of teachers and students' knowledge and understanding in facing the disasters.

The emergency response plan will be related to the early warning system in the school. If the school has a good disaster emergency response plan, the early warning system will also be good. Based on Fig. 2, the index of early warning system only reached 27.27, which indicates that early warning was in the not ready category. The schools provided a very limited disaster warnings; the schools usually only used kentongan as a disaster warning device. The development of science and technology had not been able to be utilized properly by the schools in disaster-prone areas. If students are late in getting disaster information, students will be more vulnerable to become victims of the disaster. The collaboration between schools, government, and private institutions in realizing early warning devices is needed.

The fact that the schools are located in disaster-prone areas did not encourage the schools to implement policies for integrating disaster material in the relevant subjects or in extracurricular activities. The integration is done to increase students' knowledge and understanding in facing the disasters. Without the integration, the students will not get the updated information of the disasters. 


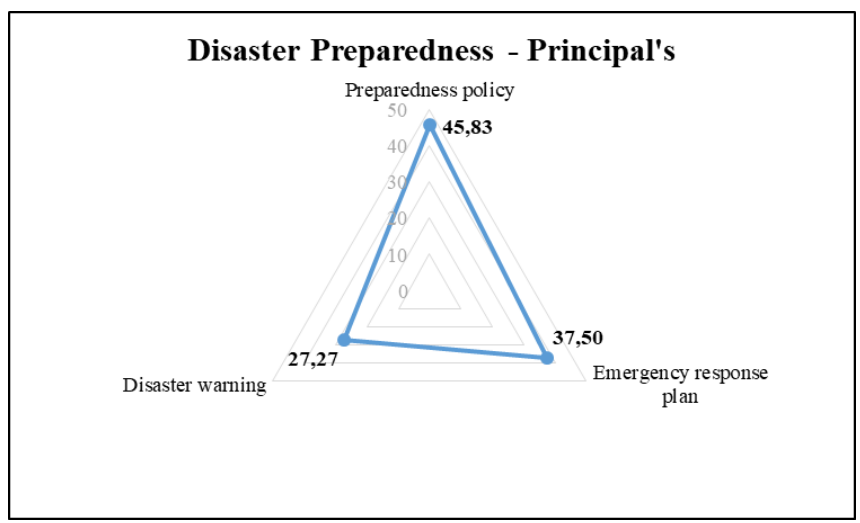

Fig. 2. Perception of Principal's Preparedness

\subsection{The Level of School's Preparedness in Realizing Safe School}

The level of school preparedness in facing disasters in Karanganyar Regency is on less ready level, especially in terms of school's principals. This can be seen from the low aspects of preparedness policies, emergency response plan, and early warning device. The principal had not been able to formulate the disaster policies in accordance with the conditions of the region. Disasters can occur in any place and any time, and if the school does not have the preparedness in facing the disaster, the number of the victims will increase. With the disaster policy in school, teachers and students are able to obtain and implement the disaster information that they already known. The teachers often do not apply the disaster knowledge they have when there are no policies that regulate the disaster in their schools. In this research, teachers have a better index than the principal. The teacher had experience in facing disasters, therefore teacher's preparedness in facing the disasters was better. Teachers must always be involved in developing disaster-safe schools, especially for schools in disaster-prone areas. The teacher is a person who is close and able to guide students while in school so their role is highly preferred.

\section{Conclusion}

Indonesia is a country that has a very high disaster risk, however, many schools are still in disaster-prone areas. Schools in disaster-prone areas should be able to become safe schools because students will be easier to learn if they are in safe situations or conditions. Elementary school students are a group that is very vulnerable to disasters. If the school does not have the preparedness in facing disasters, students will be easier to become the victims of disasters. School's preparedness in developing safe schools requires collaboration between teachers and principals. Even though the teacher has a good preparedness index (71.12), if it is not matched by the good preparedness of principal, a safe school never realized. The principal in the study location has a "not ready" category, with an index value of 36.87. The improvement of the 
principal's understanding of disasters in disaster-prone areas is needed. This understanding can be used by the principal to make disaster policies and plans so the students are able to become a disaster resilient generations. A disaster resilient generation will be realized if the school is able to become a disaster-safe school.

\section{Acknowledgments.}

We thank LIPI (Indonesian science institute) for providing specific methods for calculating preparedness. We would also like to show our gratitude to the Muhammadiyah school for giving permission and assisting in the conduct of this research.

\section{References}

[1] Aboobacker, N. P.: Gender Mainstreaming in Disaster Management Policies: Indicators to Mitigate Vulnerability of Women. Universitas Yourk (2011)

[2] Anderson, W. A.: Disaster Warning and Communication Processes in Two Communities, Journal of Communication. Vol. 19(2), pp. 92-104. doi.org/10.1111/j.1460-2466.1969.tb00834.x (1969)

[3] Astor, R. A., Guerra, N., \& VanAcker, R.: How can we improve school safety research?. Educational Researcher. Vol. 39(1), pp. 69-78. doi.org/10.3102/0013189X09357619 (2010)

[4] Baytiyeh, H.: Can Disaster Risk Education Reduce the Impacts of Recurring Disasters on Developing Societies?. Education and Urban Society, pp. 1-16. doi: 10.1177/0013124517713111 (2017)

[5] C Lesmana, P Nurul.: Kesiapsiagaan Komunitas Sekolah dalam Menghadapi Bencana di Kabupaten Magelang (Preparedness of School Communities in Facing Disasters in Magelang District). Jurnal Teknik Sipil. Vol. 11(1), pp. 1-75 (2015)

[6] Dariyo, A.: Dasar-dasar Pedagogi Modern (Basic of Modern Pedagogy). Jakarta: Indeks (2013)

[7] Enarson, E, and P.G.Dhar Chakrabarti.: Women Gender and Disaster Global Issues and Initiatives. India: Sage Publications Pvt.Ltd (2009)

[8] F Herdwiyanti, Sudaryono.: Perbedaan Kesiapsiagaan Menghadapi Bencana Ditinjau dari Tingkat Self-Efficacy pada Anak Usia Sekolah Dasar di Daerah Dampak Bencana Gunung Kelud (Differences in Disaster Preparedness Judging from the Level of Self-Efficacy in Elementary School Children in the Mount Kelud). Jurnal Psikologi Kepribadian dan Sosial. Vol. 1(03), pp. 136141 (2012)

[9] Hermon, D., P. Iskarni., O. Oktorie., and R. Wilis.: The Model of Land Cover Change into Settlement Area and Tin Mining and its Affecting Factors in Belitung Island, Indonesia. Journal of Environment and Earth Science. Vol. 7(6), pp. 32-39 (2017)

[10] LIPI.: Panduan Monitoring dan Evaluasi Sekolah Siaga Bencana (Guidance of safe school monitoring and evaluation). LIPI Press (2011) 
[11] Hilman, S.: Hubungan Self Efficacy Dengan Kesiapsiagaan Bencana Gempa Bumi Dan Tsunami Pada Siswa Sekolah Menengah Atas Negeri 2 dan 6 Banda Aceh (Relationship between Self Efficacy and Disaster Preparedness of Earthquake and Tsunami in High School Students of 2 and 6 Banda Aceh). Idea Nursing Journal. Vol. VI(2), pp. 53-61 (2015)

[12] Karanci, A. N., B. Aksit, et al.: Impact of A Community Disaster Awareness Training Program in Turkey: Does It Influence HazardRelated Cognitions and Preparedness Behaviors. Social Behavior and Personality: An International Journal. Vol. 33(3), pp. 243-258. doi.org/10.2224/sbp.2005.33.3.243 (2005)

[13] KPB.: Kerangka Kerja Sekolah Siaga Bencana (Framework of Disaster School Preparedness). Konsorsium Pendidikan Bencana (KPB) (2011)

[14] Maidaneli dan Ernawati.: Kesiapsiagaan Sekolah Dasar dalam Menghadapi Bencana Gempa Bumi dan Tsunami di Kecamatan Pariaman Tengah Kota Pariaman (Primary School Preparedness in Facing Earthquake and Tsunami in Central Pariaman District, Pariaman City). Jurnal Kapita Selekta Geografi. Vol. 2(1), pp. 89-100 (2019)

[15] Oktorie, O.: Model Kebijakan Responsif Pemulihan Bencana Letusan Gunung Sinabung (Model of Responsive Disaster Policy in the Eruption Mount Sinabung). Jurnal Kapita Selekta Geografi. Vol. 1(1), pp. 15-20 (2018)

[16] Putra \& Mutmainah.: The Mapping of Temporary Evacuation Site (TES) and Tsunami Evacuation Routein North Pagai Island, Mentawai Islands Regency - Indonesia. IOP Conference Series: Earth and Environmental Science, Vol. 47(1), pp. 012020. doi:10.1088/17551315/47/1/012020 (2016)

[17] Reeves, M. A., Kanan, L. M., \& Plog, A. E.: Comprehensive Planning for Safe Learning Environments: A School Professional's Guide to Integrating Physical and Psychological Safety, Prevention Through Recovery. Emotional and Behavioural Difficulties, Vol. 16(1), pp. 107-109. doi.org/10.1080/13632752.2011.545654 (2010)

[18] Ripski, M. B., \& Gregory, A.: Unfair, Unsafe, and Unwelcome: Do High School Students' Perceptions of Unfairness, Hostility, and Victimization in School Predict Engagement and Achievement?. Journal of School Violence. Vol. 8(4), pp. 355-375. doi:10. 1080/15388220903132755 (2009)

[19] Ronan, K. R., Johnston, D. M., Daly, M., and Fairley, R.: School Children's Risk Perceptions and Preparedness: A Hazards Education Survey. Australasian Journal of Disaster and Trauma Studies. Vol. 1, pp. 2001-2001 (2001)

[20] Ronan, K. R., and Johnston, D. M.: Hazards Education for Youth: A Quasi-Experimental Investigation. Risk Anal. Vol 23, pp. 1009-1020. doi: 10.1111/1539-6924.00377 (2003)

[21] Ssekamaya., Mastura, Badzis., Khamsiah, Ismail., Dayang, Shuzaidah.: Predictors of School Safety Awareness Among Malaysian Primary School Teachers. European Journal of Social Sciences Education and Research. Vol. 3(1), pp. 88 -93 (2016)

[22] Terpstra, T.: Emotions, Trust, and Perceived Risk: Affective and Cognitive Routes to Flood Preparedness Behavior. Risk Analysis. Vol. 31(10), pp. 1658-1675. doi: 10.1111/j.15396924.2011.01616.x (2011) 
[23] Varela, J. J., Zimmerman, M.A., Ryan, A. M., Stoddard, S., Heinze, J. E., \& Alfaro, J.: Life satisfaction, school satisfaction, and school violence: A mediation analysis for Chilean adolescent victims and perpetrators. Child Indicators Research. Vol.1-19. doi:10.1007/s12187-016-9442-7 (2017) 